\title{
紅茶の色素 カテキンの酸化について
}

\author{
滰 野 㢇 則*
}

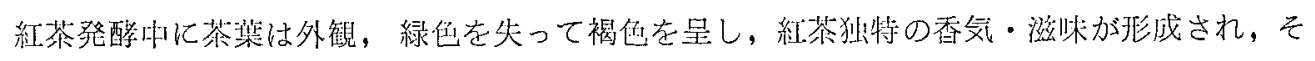

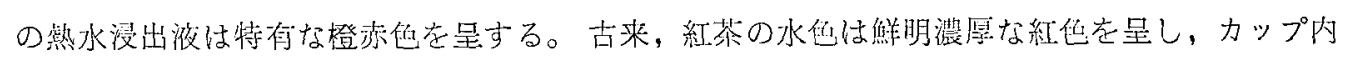
媔周縁にそって円形に黄金色を州びるのが僈良とされ，欧米人はこれを very bright attractive golden color と表現する。水仾は香気ととあに紅茶品質の優劣を左右する重要な亚素で，それ がいかなる成分・棈造に基づくかは化学的に與味深いのみならず，その本体・生成機棈の究明

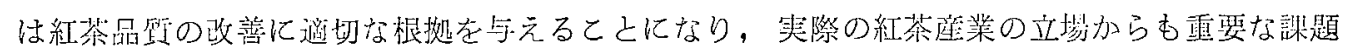
である。

紅茶水色に関係する成分として注目されるのは，原葉に含まれるフラボン色絜と裂造工程中 にカテキンの酸化によって生ずる赤色色素で，特に後者が大きな役制を演ずる。カテキンの酸

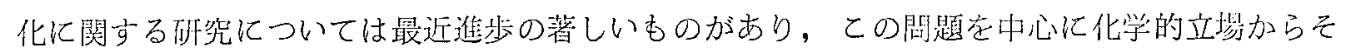
の大垡学逃べる。

\section{1 茶葉のポリフェノール成分}

紅茶発䤀中に赤変する原因物質はポリフェノール成分で, 酸化䤏素（ポリフェノールオキシ ダーゼ）の作用をうけて着色物質となるととは占くからよく知られている。茶生晸にはきわめ て多数のポリフェノールが含ま机るが，含量が高く重要なのはカテキン類である。

カテキン類は元来無色, 収れん性の強い物質で, 容易に酸化をうけて維合あるいは重合して 発色し, 漱次高分子物唕へと変化し, 収れん性が減少する。高度の重合物は暗褐色, 水に不溶 性のフロバフェンである。乙れまでにカテキンおよび関连フェノール性化合物の酸化重合・維 合の問題は植物体内における緧合型タンニン形成，植物体の微生物やウイルス感染に対する抵

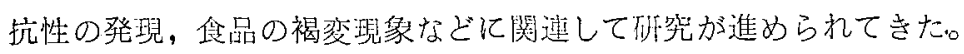

紅茶製造は褐变現象を有効に利用したものとみるととができる。茶葉力デンの主たるもの は(十)-エピカテキン (EC, XXIX)，(十)エピガロカテキン ( $\mathrm{EG}, \mathrm{XXX})$ およびそれらの没俍

\footnotetext{
* 東京教育大学㖘学部
} 
子酸エステル (ECg, EGg) で，わずかに (十)カテキン ((十) Cat)，(甘)-ガロカテキンも含まれ る。とれらの特徵はB琵に結合するフェノール性水酸㻗が 2 個（o-dihydroxyphenyl，カテコ 一ル型）か，3個（vic-trihydroxyphenyl，ピロガロル型）かの相違で，炭絜骨格・その他の 水酸基の位蹎は同じ，また，主たる前 4 者においては C-2，3 位の立体配位も全く同一であ る。

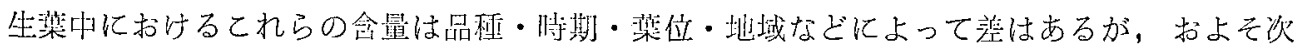
のとおりである。

$\begin{array}{ccccccc}\text { 品 } & \text { 租 } & \text { ECg } & \text { EC } & \text { EGg } & \text { EG } & \text { 計 } \\ \text { やぶきた } & 2.3 \sim 4.3 & 1.2 \sim 1.4 & 6.4 \sim 14.4 & 2.9 \sim 5.2 & 14.7 \sim 21.5 \\ \text { ベにほ ほ } & & 3.2 \sim 4.9 & 1.2 \sim 2.2 & 10.8 \sim 14.8 & 2.6 \sim 6.8 & 20.4 \sim 28.1\end{array}$

注: 数值は乾物量\%, 茶芽上位 3 亲までの含有監

$\mathrm{EGg}>\mathrm{EG} \geqq \mathrm{ECg}>\mathrm{EC}$ の一般的傾向が認められ，エステル型 $(\mathrm{EGg}+\mathrm{ECg})$ がカテキン総量 の60〜70\%を占め，また，ピロガロル型（EG+EGg）がカテコール 型（EC+ECg）より多 W。

酸化にあたってはとのようなカテキン構造の相違に基づいて，それぞ特有な变化方式を之 るであろうし，また，そ狆らの含量・混合比の相造・反応条件に㐫じて，変化の方向之生成物 の制合屯舆なるむの上洘えられる。

\section{2 (十)-カテキンの重合}

カテキンの変化に関する従来のおむな研究は植物タンニン形成機桠の解明を目的とした (十) Cat の酸触媒重合反応と自動酸化反応である。

FREUDENBERG らは（十Ｃatに対する鉱酸の作用を調べ，生成物として dicatechin（無定班） を分離した。その構造については結晶性 hendeca-acetate の性状ならびに近縁 hydroxyflavane 類を用いたモデル実験の結果を総合してIまたは扛を推定した。その後，このような酸触媒 重合反応のモデルとして (H) Cat とフロログルシンやレン゙ルシンとの反応む検傠された。最近 hendeca-acetate 加ら誘頮した diacetyl-nonamethyldicatechin のマススペクトル分析 (MS) によってとの式の妥当性が立証された。IまたはII式のいずれであるかは確定されないが，力 テキンの C-6 と C-8 位の反応性からみてII式をとりたいとしている。このほか MAYER ら,

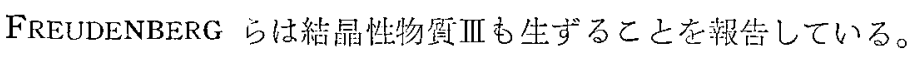

FREUDENBERG によるよ dicatechin は皮をなめす作用があり，このような变化が植物体内 

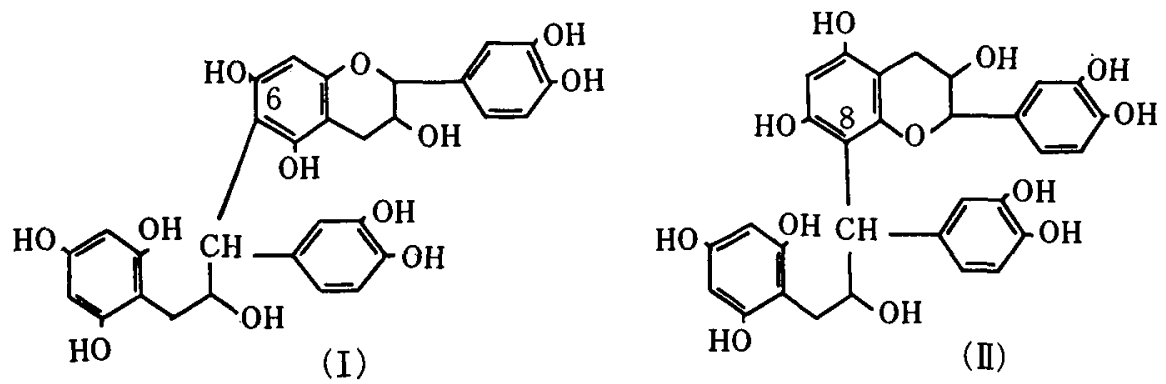

にタンニンが沈着する一要因であるという。BHANU らにより Acacia arabica の樹皮に (十)-dicatechin の存在が報ぜられたととは興味がある。しかし，植物の維合型タンニンとしては 今日一般に proanthocyanidin 型が社目されている。

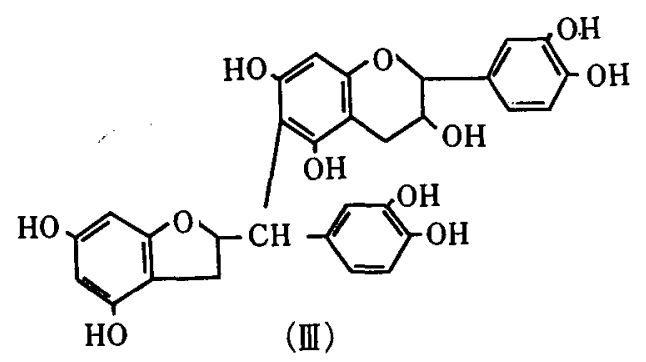

一方 HATHWAY らは (十) Cat の自動酸化について矿究し, カテキンが $\mathrm{pH} 6 \sim 8,35^{\circ} \mathrm{C}$ で 自動酸化して生ずる重合体は，マシュルーム, バレイショ, タバコなどの睃化酵素によって生 ずる重合体と同様の吸収 $\left(270,410 \mathrm{~m} \mu, 500 \mathrm{~m} \mu\right.$ 肩), 元素組成 $\left(\mathrm{C}_{15} \mathrm{H}_{10} \mathrm{O}_{6} \cdot 3 \mathrm{H}_{2} \mathrm{O}\right)$ を示すと と，カテキンをジオキサン中硝酸銀で酸化するとカテコールの埸合と同じく $370 \mathrm{~m} \mu$ に吸収極 大が見和机るととから，カテキンはキノン重合をなすものと考えた。重合体の吸収が homocatechol と 5-methoxy-4-methyl resorcinol を酸化酵装で処理した時のモデル反応生成物の吸 収に近似することから，カテキンのA環とB環が結合に関与するとして，IV式のような“ headto-tail” 重合説を提唱した。この重合体を還元後、メチル化して過マンガン酸カリ分解を行な

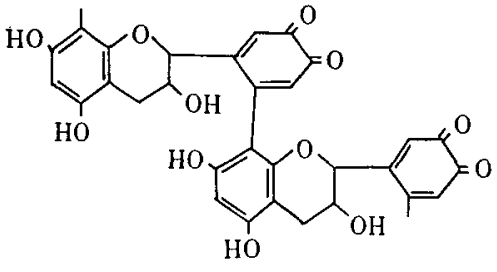

(IV)<smiles>Oc1ccc(C2Oc3cc(O)cc(O)c3CC2O)c(O)c1</smiles>

(V)

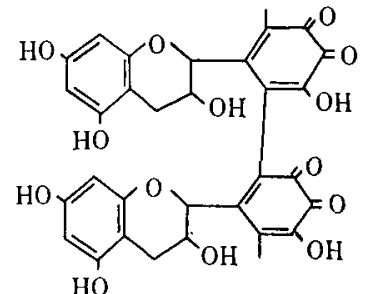

(V) 
うと $m$-hemipinic acid を生ずるととはその有力な根拋となる。Polyporus versicolor の

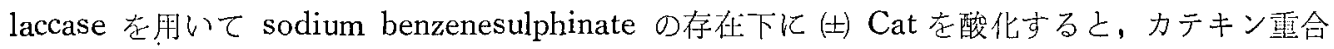
体の班成が阻止されて，6'-phenylsulphonylcatechin（VI）が生ずる（BROWN ら）ととからも C-6' 位の庈圭性がうかがえる。

HATHWAY らは Uncaria gambir の梁や Acacia catechu の心材から得られるフロバタン ニンとカテキン自勘酸化物の吸収スペクトルが類似することから，上䛉植物体内におけるタン ニン形成はこのようなカテキンの好気的酸化によるものと推定した。

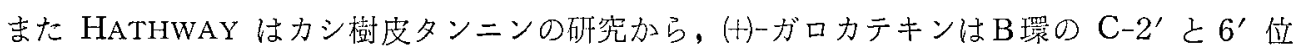
で順次結合して “tail-to-tail” 重合をし，VI型重合体を生ずるとしてタンニン沈着の説明を試 みた。

\section{3 紅茶色素の成分}

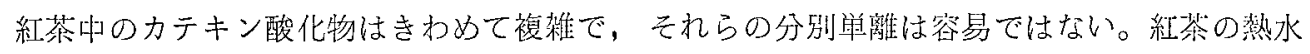
抽出液を硫酸で酸性にすると酸化物はかなり沈跑する。BRADFIELD らは酢酸エチル速続扗出 により生成物をつのフラクションに分けた。KURSANOV らは紅茶芫 Soxhlet 用いてベン ゼン，酢酸エチル拉よびエタノールで順次抽出して分別を試みた。

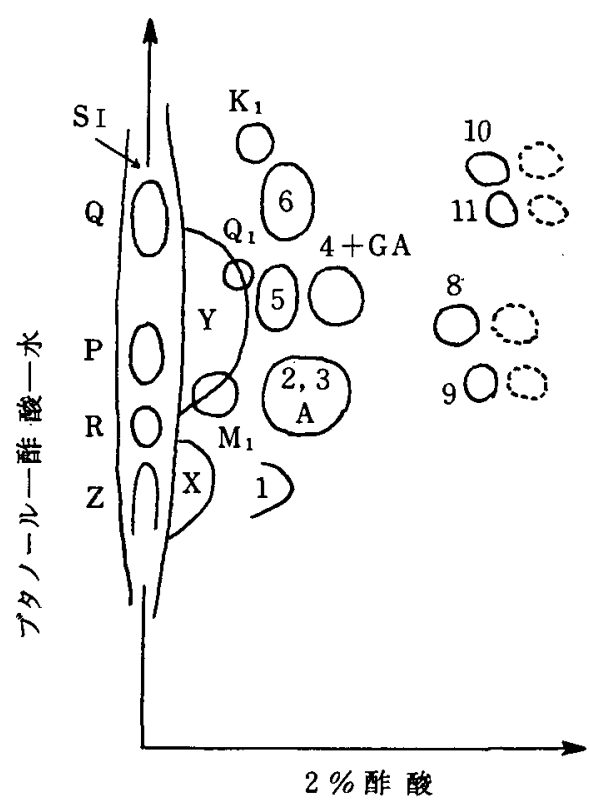

(a) 酶酸エチル可溶部

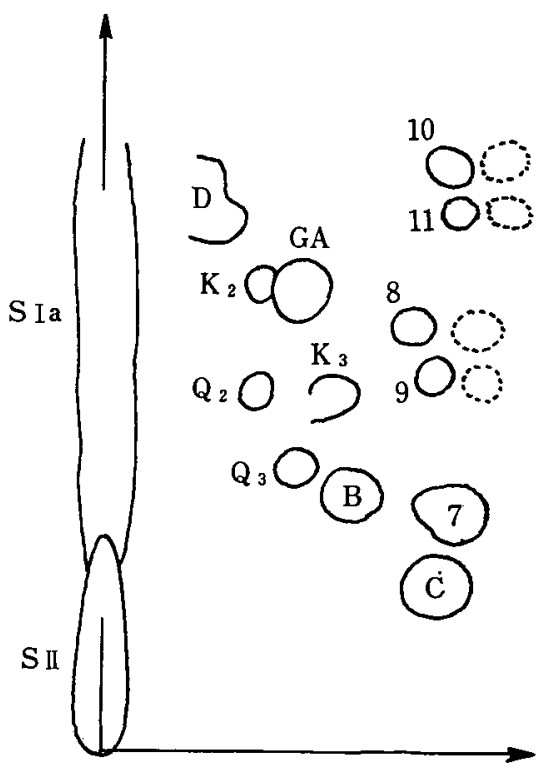

(b) 酢酸エチル不溶部

図 1 紅茶熱水抽出液のクロマトグラム 
しかし，紅茶中のカテキン酸化物の分別が有効に行なわれ，その内容が理解されるようにな ったのはペーパークロマトグラフ法 (PPC) が適用されるようになってからである。ROBERTS らはこの方法により紅茶カテキン酸化物の検索を試み， $\mathrm{A}, \mathrm{B}, \mathrm{C}, \mathrm{P}, \mathrm{Q}, \mathrm{R}, \mathrm{S}_{\mathrm{I}}, \mathrm{S}_{\mathrm{I}} \mathrm{a}$,

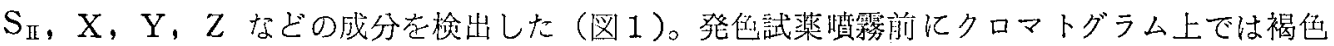

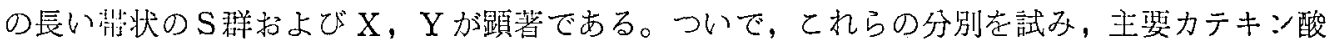
化物にテアフラビン (theaflavin, TF) およびテアルビジン (thearubigin, TR) なる名称を与. えた。前者は鮮明な橙赤色を呈する成分で, 酢酸エチルに溶けやすい。 $\mathrm{X}, \mathrm{Y}$ がこれに相当 し，YはXの没全子酸エステルである。後者は“rusty-brown substance of tea”の意で，暗

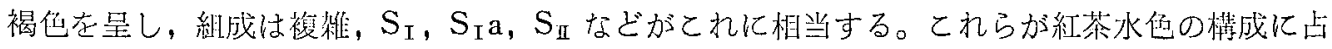
める比重はきわめて大きい。

茶葉は酸化酵素のほかにタンナーゼ在含み, 発睹岖にカデンの变化ととあに没食子酸が多 量に遊離してくる。ROBERTS は発酵中に変化するものはもっぱら EG とEGg であると考え， その反応機棈として，カテキンはキノン態を経て 2 分于結合して 2 量体 biflavanols (A，B， C）を生じ，ついでこれらが変化して発色し，TF を経て TR を生ずるむのとし，てれらの色 素に刘して推定構造式を提出した。しかし，化学的根拠に乏しく，それらの槛造・形成経路屯 今日否定されるに至った。また P (VII)，Q（purpurogallincarboxylic acid， R の gallate な どの混令と推測)，R (flavanotropolone)，Z（VIII）にもそれぞれ推定式を提出したが，十分 確認されていない。

発酕中 $\mathrm{EG}$ 巴 $\mathrm{EGg}$ のごときピロガロル型カテキンの変化がカテコール型のものに比べ顕著 なととは観祭されるが，BHATIA らあ生葉と製造後の紅茶に含まれるカテキン含踏を比較し，<smiles>Oc1cc(O)c2c(c1)OC(OOC(O)c1cc(C3Oc4cc(O)cc(O)c4CC3O)cc(O)c1O)C2</smiles><smiles>O=C(OOC1Oc2c(O)cc(O)cc2OC1c1cc(O)c(O)c(O)c1)c1cc(O)c(O)c2oc3c(O)cc(O)c(O)c3c12</smiles> 


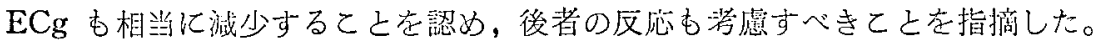

\section{4 茶葉カテキンの酸化}

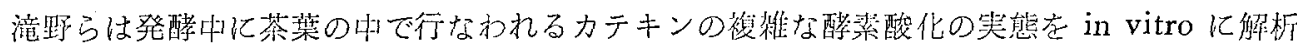

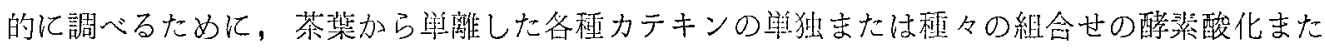
は酸化剤酸化を行なって生成物を检索分離し，また一方，紅茶加り色素を分別染離して比較同 定した。中川らもまた各種カテキンの 2 種あるいは 3 種の組合せについて醳䋕酸化を行なって 反応生成物を PPC で検索した。

(1) ピロガロル型カテキンの酸化, ビフェニル型 2 量体の形成

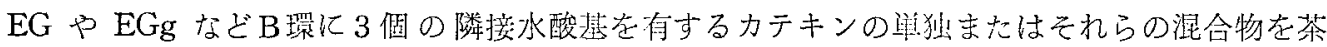
葉酸化䣼䒺で酸化すると PPC（図2）に おいて原物質に対して矢印方向に位置する 物買 $\mathrm{A}_{1} \mathrm{~A}_{2}$ (EG 羊独酸化, ROBERTS $の \mathrm{C}$ 飞相当 $), B(\mathrm{EG}+\mathrm{EGg}$ 混含酸化， B ) 拈よび C（EGg 塑独酸化，A）を生ずる。 B扩よびCはタンナーゼにより没食子酸を 放出して $\mathrm{A}_{1}$ となる。したがって，とれら の北成にはカテキン部，特にそのB環部が 関与するものと考元られる。B環に㥵当す るモデルとして没食子酸エチル（IX，図 2 の Eg）荙酵装酸化すると2 量体 diethyl $4,4^{\prime}, 5,5^{\prime}, 6,6^{\prime}$-hexahydroxydiphenate

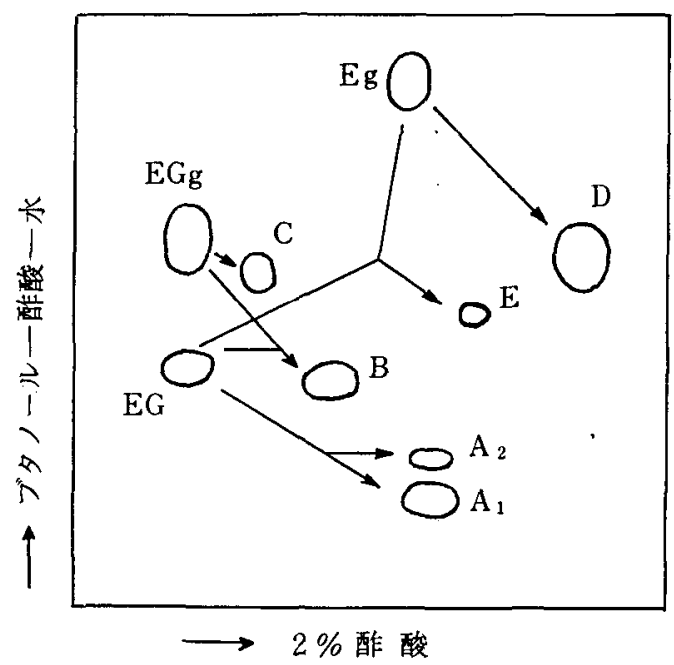

図 2 ピロガロル型カテキン招よび没食子 酸エチル $(\mathrm{Eg})$ の酵䋕酸化

（X，図2 のD）の形成が確認された。

また，興味あることには茶葉 フラボン色素の一つであるミリセチン配糖体 (myricetin-3glucoside, myricetin-3-galactoside) は他のケンフェロールやクエルセチンの配糖体に比べて<smiles>CCOC(=O)c1cc(O)c(O)c(O)c1</smiles>

(IX)

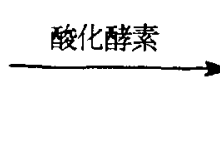

$\ldots$<smiles>CCOC(=O)c1cc(O)c(O)c(O)c1-c1c(O)c(O)cc(O)c1C(=O)OCC</smiles>

$(X)$ 
発酵中に渚しく变化して裴品中にはほとん ど認められなくなる。ミリセチンは EG と 同一の炭絜骨格と水酸等のパターン在存す るので EGの変化と対照して注目される。 色装の糖部は酸化反态にあずからないので， ミリチトリン (myricetin-3-rhamnoside) を試料として酵素酸化を試みた。ミリチト リン算独では酵素の作用をうけないが， (十) Cat またはカテコールのような $o$-dihydroxyphenyl 热を持った化合物が些存する とミリチトリンの酸化が抢こる。EGやピ ロガロルのような vic-trihydroxyphenyl

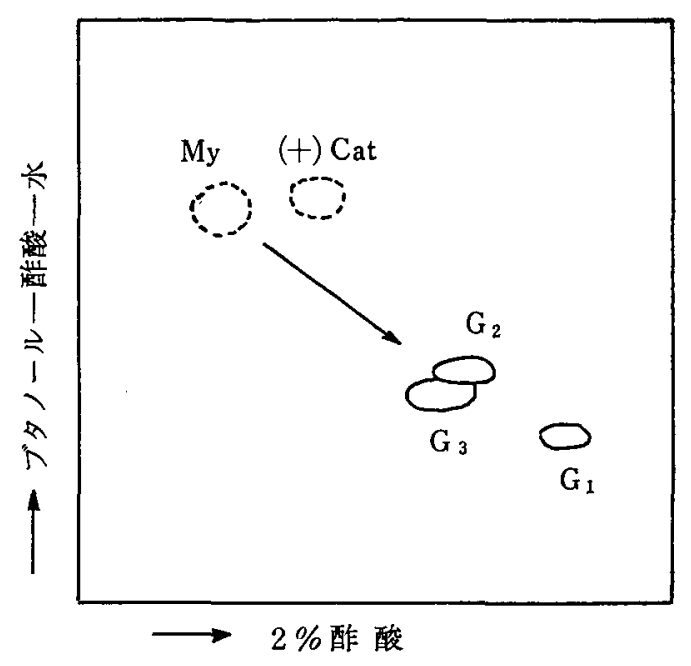

困 3 Myricitrin (My) の酵素酸化

甚を有する化合物にはその効果がない。生成物を PPC で检絷すると，前記と同方向に位䈯す る $\mathrm{G}_{1}, \mathrm{G}_{2}, \mathrm{G}_{3}$ が認められ，いずれむ黄色針状に分離された。3 者とも近似のむので，主生成

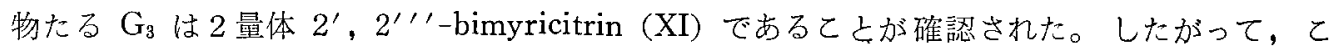
の埸合ミリチトリンは直接には酸化酵素の基質となり得ないが，カテコール型カテキンの酸化 還元的仲介によって間接的に酸化されて，ビフェニル型 2 量体を生ずるあのと判断される。

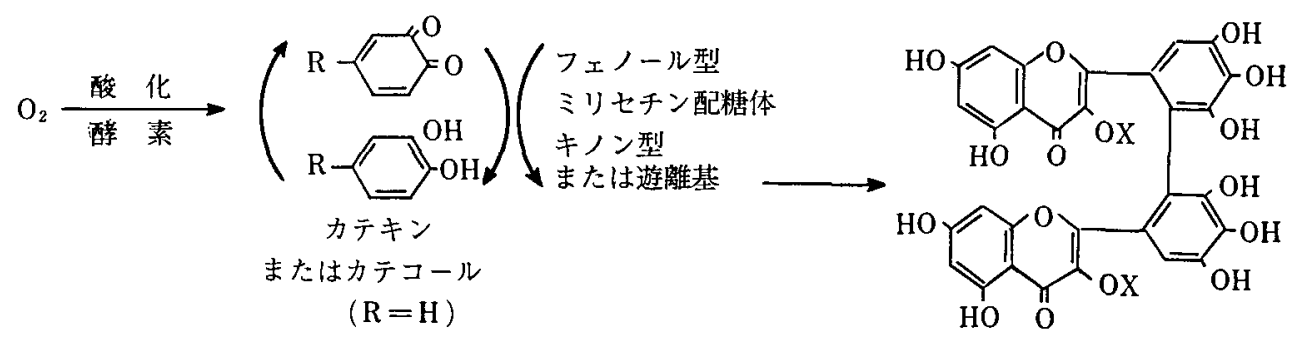

(XI)

この反応嶝酵中におりるミリセチン配糖体の変化の機棈を示すすのであるが，また，酵素 作用による二重分子フラボン色素形成の例として扔もしろい。

以上の結果を通じ，乙のようなビフェニル型 2 量体形成反応は 5 位に檤換基を有するピロガ ロル化佮物に洪通に沶てりやすい酸化反応と考えら机る。したがって，カテキン酸化生成物 A，B，Cもまた同型の 2 量体 biflavanols (XII)（Bは Aの monogallate, C は digallate) 
と判断される。VUATAZ らは紶茶からセルロースカラム分別を利用して，とれらに相当するも のを結晶状に分離した。アルカリ分解によりフロログルシンとエラグ酸が生ずるとのVUATAZ

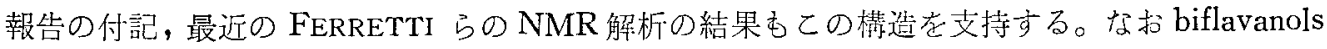
はほとえど色がない。<smiles>[R20]C1Cc2c(O)cc(O)cc2OC1c1cc(O)c(O)c(C2Oc3cc(O)cc(O)c3CC2O)c1O</smiles>

(XII)

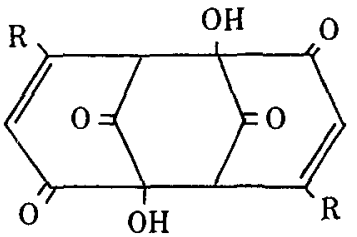

$(\mathrm{XN})$<smiles>[R]c1cc(O)c(O)c(O)c1</smiles>

(XII)

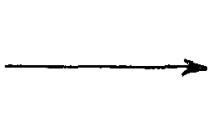
A

$\mathrm{R}=-\supset \mathrm{H}$, $\longrightarrow$ galloyl $\cdots \mathrm{B}$

$\mathrm{R}=$ galloyl $\cdots \cdots \cdots \cdots \cdots \cdots \cdots \cdot \mathrm{C}$

5 位置換ピロガロル型化合物の酸化に関しては上記ビフェニル型 2 量体形成反㐫のほかに, tricyclododecane 化合物（XIV）の形成が 5-methylpyrogallol (XIII， $\mathrm{R}=\mathrm{CH}_{3}$ ) ஓ 5-n-propylpyrogallol (XIII， $\mathrm{R}=n-\mathrm{C}_{3} \mathrm{H}_{7}$ ) の酸化に際して認められたが，カテキン酸化の埸合にはこ のような型の生成物はまだ知られていない。

(2) カテコール型とピロガロル型カテキンの壆合酸化, テアフラビン (TF) の生成と構造

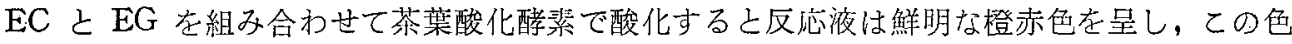
は容易に酥酸エチルに移行する。乙れを分別すると，美しい橙赤色針状結晶が得られる。この 色絜は酵素の代りに赤血塩と炭酸水素ナトリウム混液を用いて酸化反応を行なってす得られ る。これが奉際に紅茶に含まれることは，紅茶から分離した結晶色絜と完全に一致することに より確認された。とれは ROBERTS の命名した TF に相当するすのと考えられる。

その棈造については，本体招よび Al 複合体の UV・可視部吸収スペクトルが，カテコール $\left(\mathrm{XV}, \mathrm{R}_{1}=\mathrm{H}\right)$ とピロガロル $\left(\mathrm{XVI}, \mathrm{R}_{2}=\mathrm{H}\right)$ の酸化で得られる $1^{\prime}, 2^{\prime}$-dihydroxybenzotropolone (XVII) 飞特有な吸収を示すととから，とのような骨格有するすの上判断された。EC と EG からこの骨格が形成されるととを立証する一助として種 々のベンゾトロポロン化合物 (XVII, XVIII, XIX, XX) のほかに，カテコールとEG から categallin (XXI)，ピロガロール と EG から pyrogallin (XXII)，カテコールとミリチトリンから erycitrin (XXIII, erycetinrhamnoside)，(十) Cat と没食子酸の絬合色絜（XXIV）など近縁化合物を合成して，それらの 


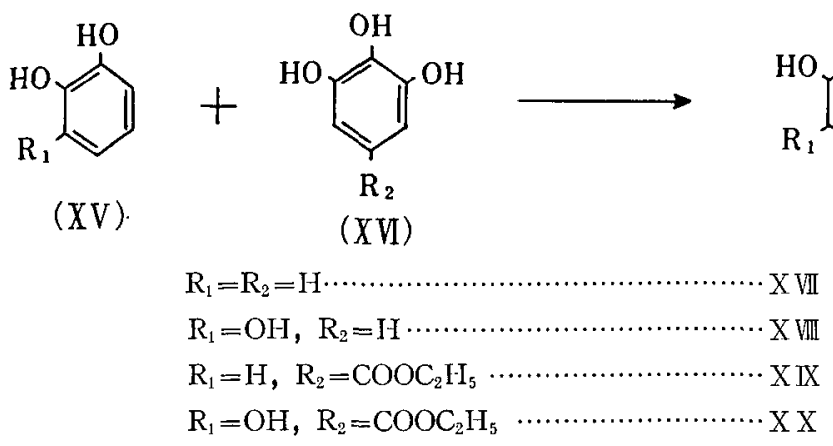

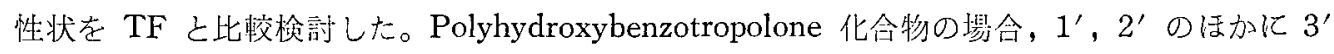
位に水酸斯を有するか否かは特にその Al 複合体の UV・可視部吸収に大きく影薌するので， これを容易に識別できる。すなわち，XVII，XIX，XXI，XXIV は 1'，2'-dihydroxybenzotropolone 型吸収老，XVIII，XX，XXII は $1^{\prime}, 2^{\prime}, 3^{\prime}$-trihydroxybenzotropolone 型吸収を 示す。

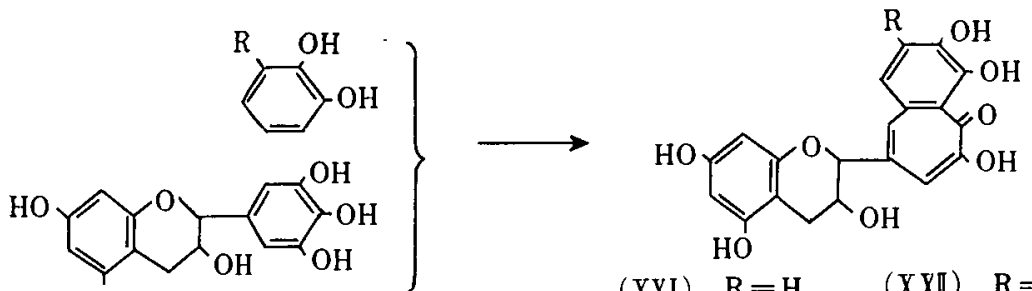<smiles>[X]c1c(-c2ccc(O)c(O)c2)oc2cc(O)cc(O)c2c1=O</smiles>

(XXI) $\mathrm{R}=\mathrm{H}, \quad(\mathrm{XXI}) \mathrm{R}=\mathrm{OH}$

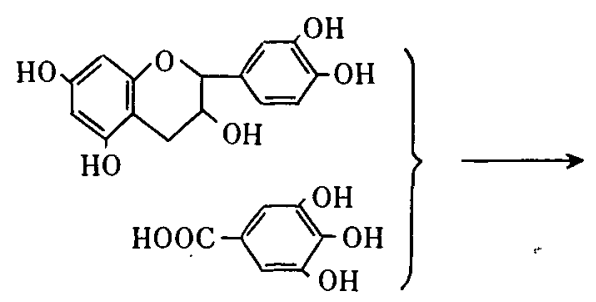<smiles>O=C(O)c1cc(O)c(O)c2c(C3Oc4cc(O)cc(O)c4CC3O)cc(O)c(O)c12</smiles>

次に $1^{\prime}, 2^{\prime}, 3^{\prime}$-trihydroxybenzotropolone 核在有する pyrogallin (XXII) は purpurogallin4-carboxylic acid (XXVI) と同梯に，アルカリ性過酸化水素分解で単環トロポロン化合物 （XXV）を生じやすいのに対して，TF をはじめ， categallin, erycetin，繀合色絜 XXIV など 


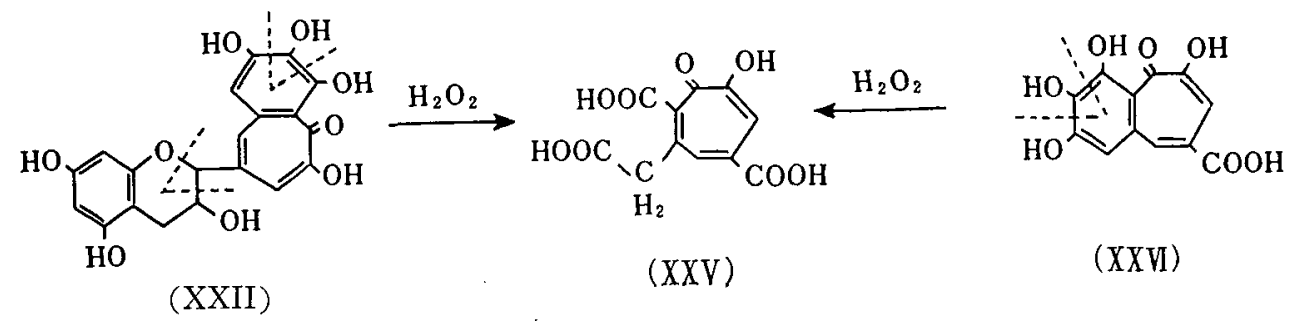

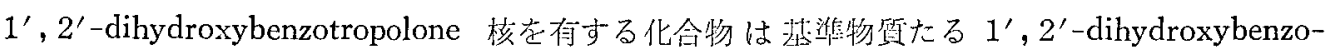
tropolone-4-carboxylic acid (XXVIII) と同様に切断と同時にトロポロン環部が転位して 6-hydroxybenzene-1，2，4-tricarboxylic acid (XXVII) を生ずる。これ屯 TF が前記骨格 を有することを示す。その全構造はさらに NMR，アセチル誘導体の分析，MS などの結果加 ら XXXI $\left(\mathrm{R}_{1}=\mathrm{R}_{2}=\mathrm{H}\right)$ であることが確認された。BROWN らも TFメチル霄導体の MS な どからこの式を支持し，ててに䄇造が確定した。したがって TFは EC と EG のB環同士が

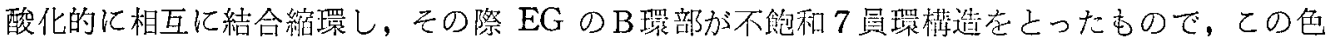
素の色はこのような構造部分に基づく。

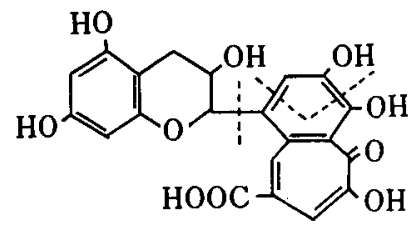<smiles>C[C@H](O)[C@H](O)C(=O)O</smiles>

(XXIV)

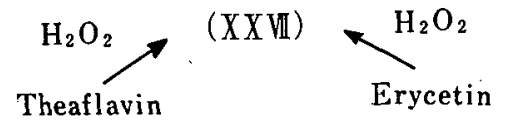

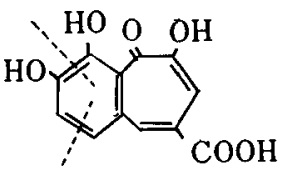

$(X X V)$

(3) エステル型テアフラビン

ROBERTS は紅茶中に TF（図1のX）のほかにその没食子酸エステル（図1のY）の存在を 示し, VUATAZ らはさらに $\mathrm{Y}_{\mathrm{II}}$ の存在を指摘した。滝野らは紅茶加ら没食子酸の結合したエ ステル型の橙色針状結晶色素 2 種を分離した。一つは TFの monogallate，他は digallate で， タンナーゼによりそれぞれ 1 モルの TF 上 1 モルまたは 2 モルの没食子酸を生ずる。てれらの 色素はそれぞれ $\mathrm{EC}+\mathrm{EGg}, \mathrm{ECg}+\mathrm{EGg}$ の組合せ酸化で合成されるすのと一致するる。このほか $\mathrm{ECg}+\mathrm{EG}$ の組合せ酸化で，上記のものと没食子酸の結合位置の翼なる monogallate 異性体も 生じ得るが, 紅茶中には十分確認はさ狆ていない。紅茶中の含量は遊離の TF よりむエステル 型, 特に monogallate のはうが多い。 


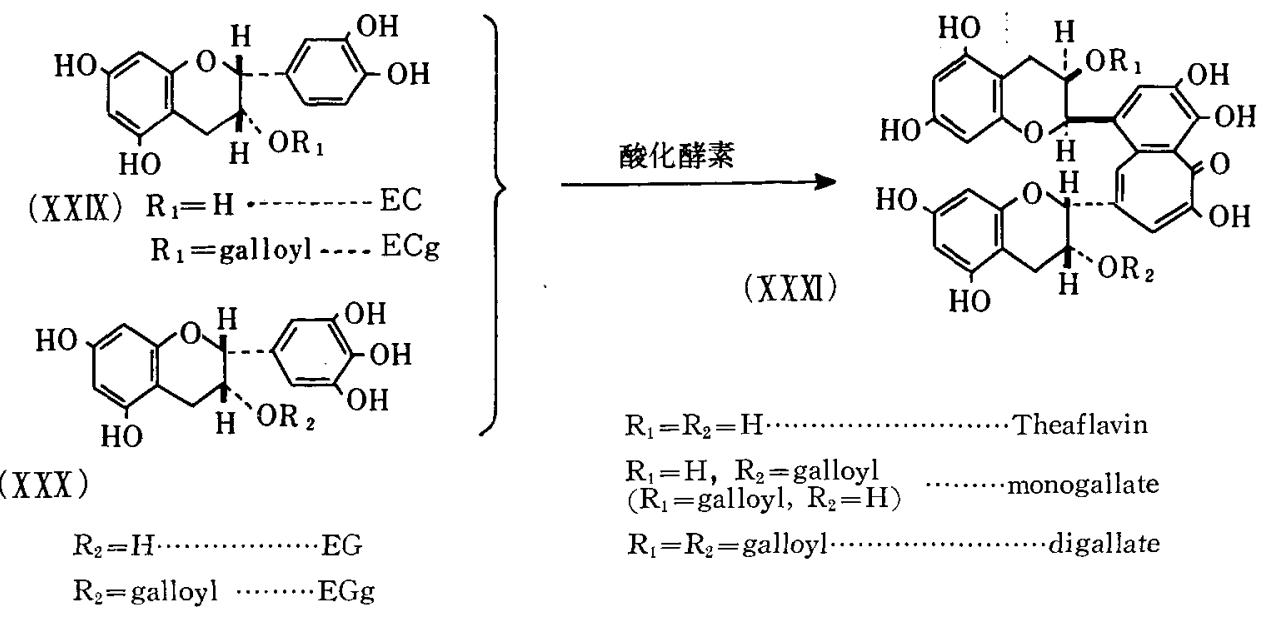

(4) カテコール型カテキンの酸化

$\mathrm{EC} や \mathrm{EG}$ のようなカテコール型カテキンむ酵素酸化により褐色のS 㥞物質, 無色の生成物 在与えるが，生成物の性状は明らかではない。滝野らは比較物質として EC の異性体 (十) Cat を試料として醉菜および酸化剂酸化を行ない，結晶性物質と重合体と考えられるS㥞物質を得 た。結晶性物質は $\mathrm{C}_{30} \mathrm{H}_{24} \mathrm{O}_{12}$ で2 分子の (H) Cat から 4 個の水素原子が離脱したものと考えら れる。WEINGES らも (H) Cat のペルオキシダーゼ酸化で同咏の物質を得ているが構造は未詳 である。な㧍，ての反応の際に 8-hydroxycatechin（XXXII）毛生ずる。<smiles>Oc1cc(O)c2c(c1)OC(c1ccc(O)c(O)c1)C(O)C2</smiles><smiles>Oc1cc(O)c2c(c1)CC(O)C(c1ccc(O)c(O)c1)O2</smiles>

(XXXII)
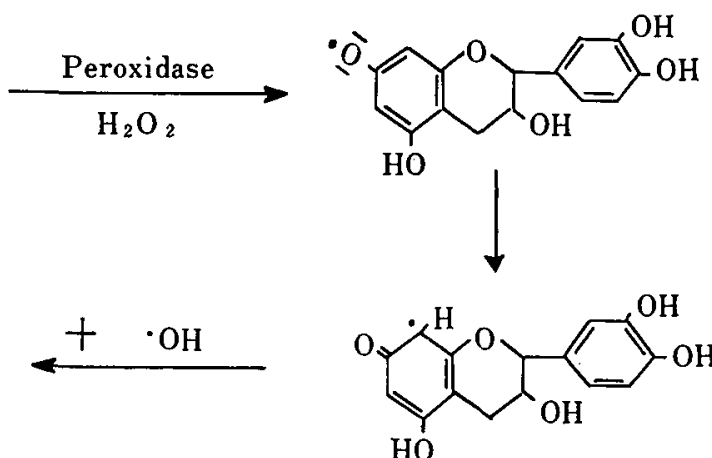<smiles>O=C1C=C(O)C2=C(C1)OC(c1ccc(O)c(O)c1)C(O)C2</smiles>

\section{5 テアルビジン (TR)}

TR はカテキン酸化物叶最も含量が高い。腤褐色無定形物留で, 組成が複雑, 㯇造・生成機 椿は不明の点が多い。ROBERTSは $\mathrm{S}_{\mathrm{I}}, \mathrm{S}_{\mathrm{I}} \mathrm{a}, \mathrm{S}_{\mathrm{II}}$ に区分したととは前記のと扝りである。酸性 物質で，その酸性はカルボキシル基によるとみられる。VUATAZ らは溶剂抽出，酢酸鉊沈殿， 
セルロースカラム分別によって得られる TR は $0.55 \% \mathrm{~N}$ を含み，てれを $5 \mathrm{~N} \mathrm{HCl}$ と $120^{\circ} \mathrm{C}$ に12時間加熱すると14種のアミノ酸が検出されることから，TRは部分的には humic acid 様 の物質から成ると推論した。おうらくカテキン酸化物とタンパク質の複合体ではなからうか。 WICKEREMASINGHE は chebulinic acid, corilagin や glucogallin との関戛を報じた。 MILLIN らはTR は分子量 700 から 40,000 あるいはこれ以上の筑围にわたる酸性物質の複雑な混合物 であるという。最近ゲルロ過によるカテキン酸化物の分別も報ぜられ，殊に Sephadex LH-20 を用いて効果があげられている。

著者らの酢酸エチル可溶性 TR についての試験では，エステル結合する没食子酸が含まれ， これを除いた残部をメチル化後過マンガン酸カリ分解すると没食子酸の trimethyl ether が得 られる。したがって，ての物質の形成には EGg が関与するむのと推測される。EGgを酸化し て得られる生成物中酢酸エチル可溶部と比較すると, UV・可視部吸収ならびに IR スペクト ルがよく一致するので，との物質の形成には EGg が主役を演ずるすのと推測される。

最近 TR の構造に関して興味あるのは BROWN らの見解である。すな水ち, 紅茶熱水浸出 液を諸種の溶剂を用いて五つのフラクションに分ち, それぞれ(1)無水イソプロパノール中で塩 酸処理すると約20\%前後の収量でシアニジン，デルフィニジンおよびそれらのイソプロピル誘

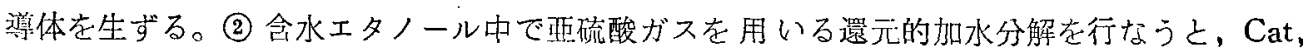
$\mathrm{EC}, \mathrm{ECg}, \mathrm{EG}, \mathrm{EGg}$ が検出され，(3)キノン態構造む認められる。とれらの結果から TR は 次の残基加ら構成される proanthocyanidin 型の緛合物で，てれらの残基は C-C および，また

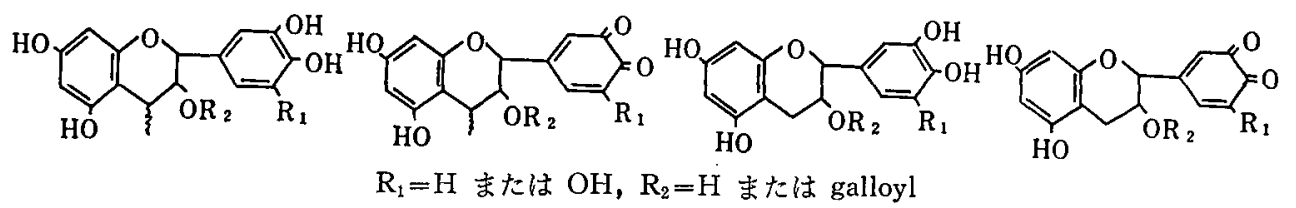

は C-O 結合で重合体構造をとっているという。結合位置 としては C-6，8，2'，6 $6^{\prime}$ 位，さ らにはフェノール性およびアルコール性酸素原子による結合もあろうと。なお，このような構 造は有機溶剂によって抽出されるTRについてであるが，抽出されない部分はポリフェノー ル・タンパク質複合体をなし，その際のポリフェノール部も上記のような proanthocyanidin 重 合体であろうと考えている。この見解はさらに検討を要する点も多いが，注目に洒する。

\section{6 紅茶発酵中におけるカテキンの酸化機構}

上記のように紅茶発酵中にお污るカテキン酸化については多くの知見が得られ，主要生成物 
の一つである TF 関係は十分解明されたが，TRについてはなお不明の点が多い。したがっ て見在紅茶発酵中に抢けるカテキン酸化の全貌をは握することはできないが，ほぼ明確にされ た部分を模式化すると図4のとおりになるう。

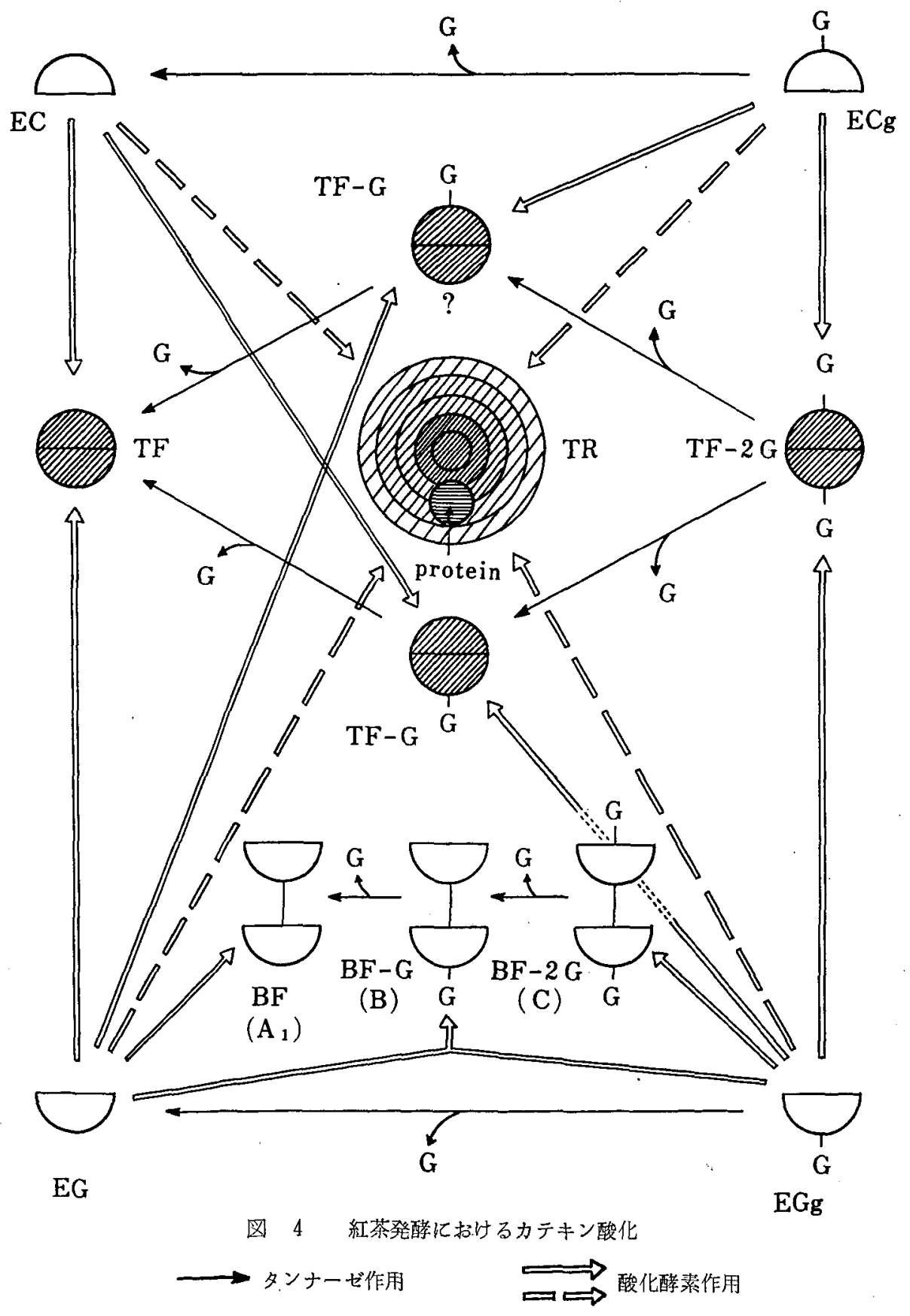




\section{7 紅茶の水色・品質とカテキン酸化物との関係}

紅茶中には未変化のカテキン, TF, TR およびタンパク質との複合体などが含まれ，セイロ ン紅茶においてはそれぞ扎 $5 ， 1 〜 2 ， 15 ， 5 \%$ 程度である。こ扎らのうち紅茶の水色に重要 な関係を有するのは TF と TR で，それらの含量と品質との関係については RoBERTs, SMITH, 坂本, 中川の研究がある。中川によると日本産紅茶高級品の 1 例は TF $0.80 \%$, TR 10.52\% で, TF は鮮かな橙赤色を呈し色調に大きく影響するが，TRはやや黑みを带び水色の 深さに関係する。TR は高級品でも下級品でもそれ程含量に大差はないが，TF 含量と水色・ 滋味の間には高い相関関係が認められ，TF 含量の高いもの，殊に TR に対する TF 比率の高 いものが水色品質良好である。

\section{文献}

1) Nakagawa, M. and H. Toril : Agr. Biol. Chem., 28, 497 (1964).

2) Freudenberg, K., J. H. Stocker and J. Porter : Ber., 90, 957 (1957); FreudenBerg, K. and K. WeInGes : Fortschr. Chem. Org. Naturstoffe, 16 , 1 (1958).

3) Weinges, K. and F. Toribio : Ann., 681, 161 (1964) ; MAYER, W. and R. LEMKE : Naturwissenschaften, 50, 644 (1963).

4) Weinges, K. and D. Nagel : Phytochem., 7, 157 (1968).

5) Mayer, W. and F. Merger : Ann., 644, 70, 79 (1961).

6) Freudenberg, K. and K. Weinges : ibid., 668, 92 (1963).

7) Bhanu, K. U., S. Rajadurai and Y. Nayudamma : Aust. J. Chem., 17, 803 (1964).

8) Hathway, D. E. and J. W. T. Seakins : Biochem. J. 67, 239 (1957).

9) Hathway, D. E. : J. Chem. Soc., 1958, 520.

10) BROWN, B. R. and WhitEOAK : ibid., 1964, 6084.

11) Hathway, D. E. : Biochem. J., 70, 34 (1958).

12) Harrison, C. J. and E. A. H. Roberts : ibid., 33, 1408 (1939).

13) Bradfield, A. E. and M. Penney : J. Soc. Chem. Ind., 43, 306 (1944).

14) Kursanov, A., K. Djemuhadze and M. Zaprometov : Biokhimiya, 12, 421 (1947).

15) Roberts, E. A. H. : The Chemistry of Flavonoid Compounds (T. A. Geissman, Pergamon Press) p. 468 (1962) ; Roberts, E. A. H., : J. Sci. Food Agr., 9, 381 (1958). 
16) Bhatia, I. S. and M. R. UllaH : Chem. and Ind., 1961, $1169 ;$ J. Sci. Food Agr., 16, 408 (1965).

17) 滝野慶則, 今川 弘：農化, 37, 417 (1963).

18) Nakagawa, M. and H. Toril : Agr. Biol. Chem., 29, 278 (1965).

19) Takino, Y., H. IMagawa, Y. AOKi and T. OzAWA : ibid, 27, 562 (1963).

20) TAkino, Y., H. IMAgawA and H. YoshidA : ibid, 26, 699 (1962).

21) IMAGawa, H. and Y. TAKINo : ibid., 26, 541 (1962).

22) Vuataz, L. and H. BRAndenberger : J. Chromatog., 5, 17 (1961).

23) Ferretti, A., V. P. Flanagan, H. A. Bondarovich and M. A. Gianturco : J. Agr. Food Chem., 16, 756 (1968).

24) Critchlow, A., E. Haslam, R. D. Haworth, P. B. Tinker and N. M. Waldron: Tetrahedron, 23, 2829 (1967).

25) Takino, Y. and H. Imagawa : Agr. Biol. Chem., 27, 319 (1963) ; Takino, Y., H. IMAgAwA, H. HorikAWA and A. TANAKA : ibid., 28, 64 (1964).

26) Takino, Y. and H. Imagawa : ibid., 28, 255 (1964).

27) TAKino, Y. and H. IMAGaWA : ibid., 28, 125 (1964).

28) Takino, Y. and H. Imagawa : ibid., 27, 666 (1963).

29）㜔野慶則, 堀川博朗, 加藤 高: 農化大会講演要旨集 128 (1966).

30) Takino, Y., A. Ferretti, V. Flanagan, M. Gianturco and M. Vogel : Tetrahedron Letters : 1965, 4019 ; ibid., 1966, 4024 ; Canadian J. Chem., 45, 1949 (1967).

31) Brown, A. G., C. P. Falshaw, E. Haslam, H. Holmes and W. D. Ollis : Tetrahedron Letters, 1966, 1193.

32）滝野慶則, 小沢哲夫, 真田宏夫：農化大会講演要旨集 75 （1965）; 滝野慶則, 小沢哲夫, 柾木茂彦：農化大会講演要旨集 128 (1966).

33）滝野慶則, 青木葉子：小沢哲夫：農化大会講演要旨集 105（1967）；71（1968）.

34) Weinges, K. and W. Ebert, Phytochem., 7, 153 (1968).

35) Wickremasinghe, R. L. : Tea Quart., 38 (2), 205 (1967).

36) Millin, D. J. and D. W. Rustidge : Process Biochem., 2, 9 (1967).

37) Crispin, D. J., R. H. PAyne and D. Swaine : J. Chromatog., 37, 118 (1968); Millin, D. J., D. Swaine and P. L. Dix : J. Sci. Food Agr., 20, 296 (1969); Millin, D. J., D. S. Sinclair and D. Swaine : ibid., 20, 303 (1969).

38）滝野慶則，小沢哲夫，白川洋一：茶技協講要 19 (March 1967). 
39) Brown, A. J., W. B. Eyton, A. Holmes and W. D. Ollis : Nature, 221, 742 (1969).

40) HARLER, C. R. : Tea Manufacture (Oxford University Press), p. 112 (1963).

41) Smith, R. F. and G. W. White : J. Sci. Food Agr, 16, 205 (1965).

42) 坂本 裕, 中田其男, 茶業技術研究: 27,55 (1963).

43）中川致之，传品工業学会誌：16，266（1969).

* 最近·WEINGES らによって次の構造式を有することが報告された〔WEINGES，K., W. Ebert, D. Huthwelker, H. Mattauch and J. Perner : Ann., 726, 114 (1969) ]。

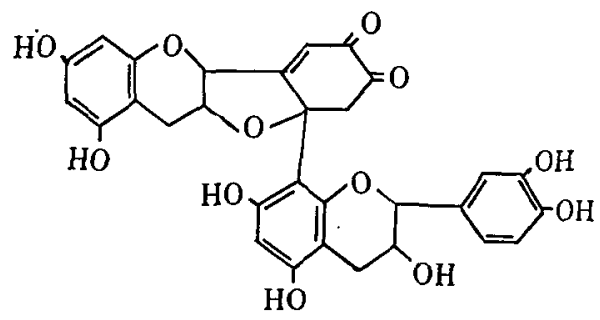

